\title{
WestVirginiaUniversity
}

THE RESEARCH REPOSITORY @ WVU

Graduate Theses, Dissertations, and Problem Reports

2005

\section{How West Virginia daily newspapers handle errors and corrections}

\author{
Lindsay E. Altobello \\ West Virginia University
}

Follow this and additional works at: https://researchrepository.wvu.edu/etd

\section{Recommended Citation}

Altobello, Lindsay E., "How West Virginia daily newspapers handle errors and corrections" (2005). Graduate Theses, Dissertations, and Problem Reports. 1574.

https://researchrepository.wvu.edu/etd/1574

This Thesis is protected by copyright and/or related rights. It has been brought to you by the The Research Repository @WVU with permission from the rights-holder(s). You are free to use this Thesis in any way that is permitted by the copyright and related rights legislation that applies to your use. For other uses you must obtain permission from the rights-holder(s) directly, unless additional rights are indicated by a Creative Commons license in the record and/ or on the work itself. This Thesis has been accepted for inclusion in WVU Graduate Theses, Dissertations, and Problem Reports collection by an authorized administrator of The Research Repository @ WVU. For more information, please contact researchrepository@mail.wvu.edu. 


\title{
HOW WEST VIRGINIA DAILY NEWSPAPERS HANDLE ERRORS AND CORRECTIONS
}

\author{
Lindsay E. Altobello \\ Thesis Submitted to the \\ Perley Isaac Reed School of Journalism \\ At West Virginia University \\ in partial fulfillment of the requirements \\ for the degree of \\ Masters of Science \\ in \\ Journalism
}

Professor John Temple, Chair
Dr. Terry Wimmer
Dr. George Esper
Dr. Brian Patterson

Morgantown, West Virginia

2005

Keywords: correction policies, newspaper accuracy 


\section{ABSTRACT \\ How West Virginia Daily Newspapers Handle Errors And Corrections \\ Lindsay E. Altobello}

Media credibility and accuracy has been a topic of debate in the field of journalism for many years. This study examines the types of errors that occur most often within West Virginia's daily newspapers; how these publications handle errors and corrections, and the placement of corrections and clarifications within the newspapers. This study uses mixed-methods research to find its results. Corrections and clarifications gathered over a 60-day time period were analyzed for the type of error corrected as well as if the error was attributed. Newspaper editors were surveyed about how their publications handle corrections and their perceptions of the type(s) of errors that occur most often. 


\section{TABLE OF CONTENTS}

HOW WEST VIRGINIA DAILY NEWSPAPERS HANDLE ERRORS AND

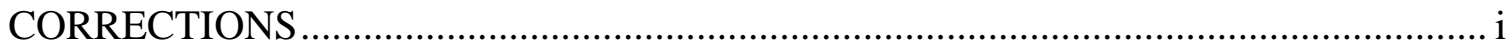

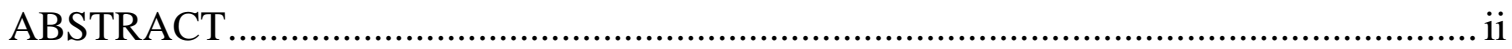

TABLE OF CONTENTS........................................................................................

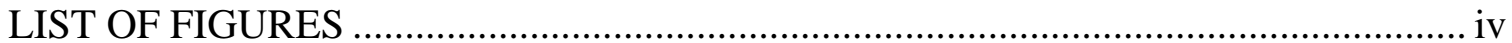

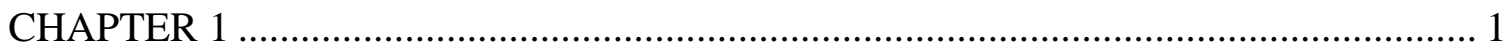

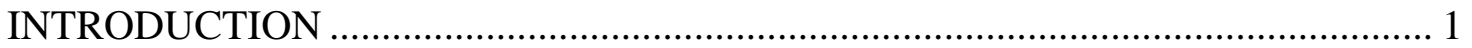

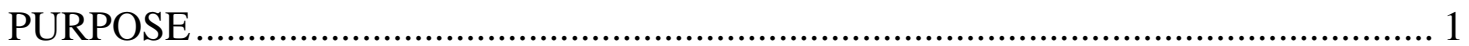

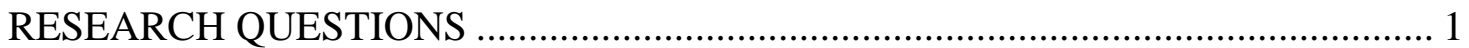

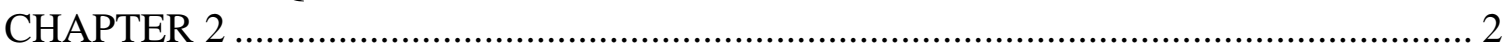

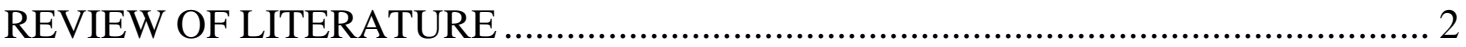

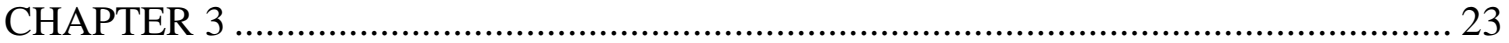

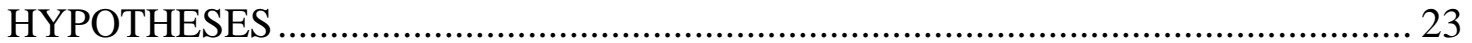

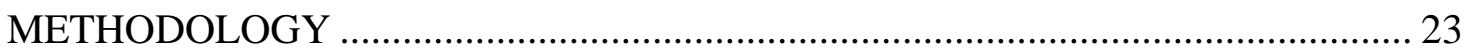

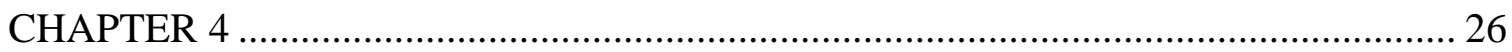

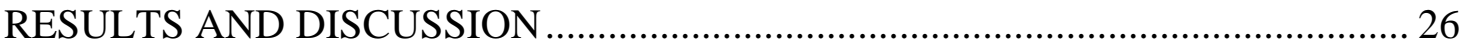

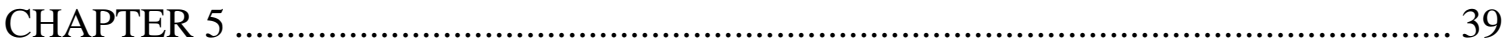

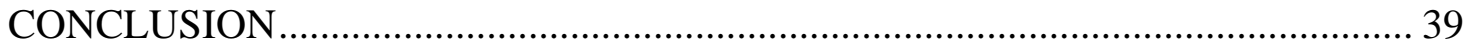

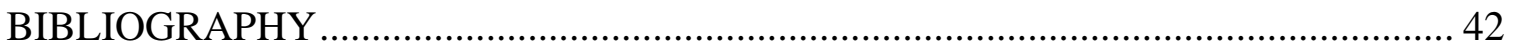

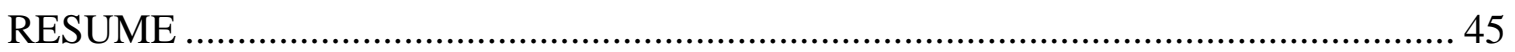




\section{LIST OF FIGURES}

Table 1. Total Number of Errors in Newspapers ........................................................... 26

Table 2. Total Number of Corrections in Each Newspaper............................................ 27

Table 3. Breakdown in the Amount of Errors in High Circulating Daily Newspapers

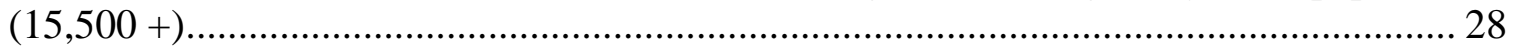

Table 4. Breakdown in the Amount of Errors in High Circulating Daily Newspapers

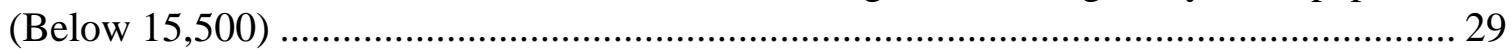

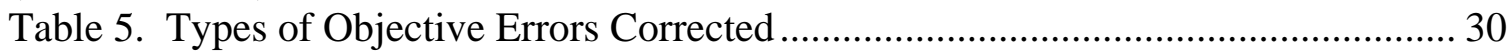

Table 6. Frequency of Subjective Errors Found …...................................................... 30

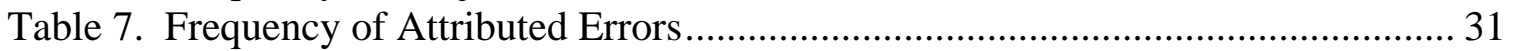

Table 8. Numbers and Percentages of Types of Errors Corrected................................... 32

Table 9. Newspaper Editors Responses to Questions One - Three................................. 33

Table 10. Newspaper Editors Responses to Questions Four and Six .............................. 36

Table 11. Locations and Positions of Corrections In Newspapers ................................ 38 


\section{CHAPTER 1}

\section{INTRODUCTION}

The credibility of the media has been the topic of discussion for many years. Studies conducted to find reasons for the loss of credibility over the years has led to various opinions. Some researchers look toward the loss of accuracy in the newspaper; others look toward the loss of ethics, or ethical journalism; and some look toward pagination and who were just copy editors now having multiple responsibilities. Along with offered reasons for the loss of credibility, efforts that can be taken in order to combat the problem are also suggested. News councils and ombudsmen as well as better fact checking are all suggestions offered to help alleviate the problem. Although the percentages of perceived accuracy by news sources and readers has remained relatively constant across the span of several decades, the credibility problem still weighs heavily on the minds of professional societies, such as the American Society of Newspaper Editors, and newspaper editors and publishers.

\section{PURPOSE}

The purpose of this study is to look at a West Virginia daily newspapers to determine how the publications handle corrections.

\section{RESEARCH QUESTIONS}

$\mathrm{R}_{1}$ : Do the majority of the publications have formal, written correction policies?

$\mathrm{R}_{2}$ : Is there a standard location where readers can find corrections within the publication?

$\mathrm{R}_{3:}$ As prior research has found, do the majority of publications tend to correct objective-type errors over subjective-type errors? 


\section{CHAPTER 2}

\section{REVIEW OF LITERATURE}

Several scholars have noted that journalists are gatekeepers. By taking on the role of a gatekeeper, a journalist is deciding what information readers are going to receive. Kurt Lewin, a German social psychologist, first developed the theory of gatekeeping and acknowledged that the food placed on the family table traveled through channels passing through gates guarded by gatekeepers. ${ }^{1}$ Lewin also noted that there are forces (e.g. personal like of a certain food, family tastes, and, idea of what foods are essential) that lead to the purchase of one food over another. ${ }^{2}$ Although his theory was not intended to apply to mass communication, Lewin remarked that it could apply to how news items flowed from one channel to another. ${ }^{3}$

David Manning White first applied Lewin's theory to the field of mass communication. White studied one wire editor, the stories he didn't use in the newspaper and the reasons why he didn't use them. "Mr. Gates," as the wire editor was dubbed for this study, only used one-tenth of the copy he received from the Associated Press, United Press and International News Service. ${ }^{4}$ Upon examining the reasons for not printing certain stories, White realized "how highly subjective, how reliant upon value-judgments based on the 'gate keeper's' own set of experiences, attitudes and expectations the

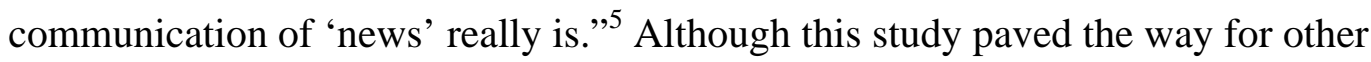

\footnotetext{
${ }^{1}$ Kurt Lewin, "Frontiers in Group Dynamics: Channels of Group Life; Social Planning and Action Research,” Human Relations 1 (November 1947): 144, 145

${ }^{2}$ Ibid.

${ }^{3}$ Ibid., 145

${ }^{4}$ David Manning White, “The 'Gate Keeper:’ A Case Study In the Selection of News,” Journalism Quarterly 27 (fall 1950): 385

${ }^{5}$ Ibid., 386
} 
gatekeeping studies within the field of mass communication, it only studied one wire editor for a one-week period. Understanding the theory of gatekeeping is important to this study since “a person's biases may lead to omission or inclusion of some items because news selections color our 'pictures' (our knowledge) of distant events.”6

Shoemaker and Reese declared there to be individual and organizational routines within a newspaper. Individual routines can include assessing newsworthiness and meeting deadlines, while organizational routines can include policies about how to cover topics and what is considered newsworthy. ${ }^{7}$ These routines may lead to the sloppiness of reporters as well as stories being published before they are properly fact-checked for errors. Along with these notions of routines the researchers also noted a hierarchy within an organization. This hierarchy can be broken into macro and micro systems with each level having its own influences. ${ }^{8}$

Studies of accuracy are not new to the field of journalism. Mitchell V. Charnley, for his 1936 study on the accuracy in newspapers, is typically regarded as the founder of accuracy studies. Charnley sent out 1,000 news stories from three Minnesota daily newspapers. Dividing the errors into categories (meaning, names, titles, figures, times, places, quotations, addresses, dates, spelling, grammar, ages, and mechanical), he found that "errors in meaning" were the most common. ${ }^{9}$

\footnotetext{
${ }^{6}$ Michael W. Singletary and Gerald Stone, Communication Theory and Research Application (Iowa State Univeristy Press, 1988), 22.

${ }^{7}$ Pamela J. Shoemaker et al., "Individual and Routine Forces in Gatekeeping,” Journalism and Mass Communication Quarterly 78 (summer 2001): 235

${ }^{8}$ Pamela J. Shoemaker and Stephen D. Reese, Mediating the Message: Theories of Influences on Mass Media Content (NY: Longman, 1996): 262

${ }^{9}$ Mitchell V. Charnley, "Preliminary Notes on A Study of Newspaper Accuracy,” Journalism Quarterly 13 (winter 1936): 398
} 
Charles H. Brown, for Editor and Publisher, conducted a study in 1965 that sent surveys to 200 persons cited as sources within news stories from 42 Oklahoma newspapers. ${ }^{10}$ Recipients were given a list of choices for possible errors including, “misquotations,” “errors in meaning,” “errors in people’s names,” and “errors in identification and title."11 The results of his study concluded that a majority of those surveyed found their stories to be accurate. The author had a response rate of 72 percent and eighty-five of the 143 items returned did not have errors. ${ }^{12}$ The 58 stories that were returned noting inaccuracies had 123 errors with "miscellaneous factual errors” ranking highest with $32 .^{13}$ These types of errors were found in information gathered by reporters through interviewing sources. Brown also addressed the idea of judging accuracy by the number of words in a story and the column inches it took up in the newspaper. 661 column inches and 25, 779 words had errors while 844 inches and 32,916 where errorfree. $^{14}$

Following Brown, in 1967, Berry studied stories produced from three California newspapers, two afternoon and one morning. Brown hypothesized that as the time to produce a news story decreased the number of inaccuracies increases; more inaccuracies will be the product of more handling of facts; and news item accuracy varies when

\footnotetext{
${ }^{10}$ Charles H. Brown, “Majority of Readers Give Papers and A for Accuracy,” Editor and Publisher (1965): 13, 63.

${ }^{11}$ Ibid., 13

${ }^{12}$ Ibid.

${ }^{13}$ Ibid.

${ }^{14}$ Ibid.
} 
different sources are involved. ${ }^{15}$ Following in the footsteps of Charnley and Brown, a questionnaire was sent to 506 persons; however, only 270 were used in the study.

The author was not as concerned with typographical errors, but noted 52.2 percent of the stories were error free, 46.3 percent when the typographical errors were included. ${ }^{16}$ The three papers, San Francisco Examiner and Chronicle and Palo Alto Times, rated relatively equal on the percentage of stories that were error free. ${ }^{17}$ Stories from the three papers were then broken down into the two classifications of news stories; spot and anticipated. The Chronicle faired best on spot stories with an accuracy rate of 55 percent, but the Times faired best on anticipated stories with an accuracy rate of 56 percent. ${ }^{18}$ The accuracy of the papers was further broken down into "objective” and "subjective" error categories. "Objective” errors, those of name and age, were most commonly found in "spot" stories. ${ }^{19}$ All three studies found that subjective errors, or as Charnley noted "errors of meaning," ${ }^{20}$ were the most common and offered that reporters use a single question: "What is the significance of this event?"21 to ensure accuracy. "A reporter loses no interpretaive independence by asking this question. It forces persons involved in events to focus and summarize for the newsman, and many in fact help speed the reporter’s comprehension of complicated issues."22

\footnotetext{
${ }^{15}$ Fred Berry, “A Study of Accuracy,” 483

${ }^{16}$ Ibid., 484

${ }^{17}$ Ibid., 486

${ }^{18}$ Ibid.

${ }^{19}$ Ibid.

${ }^{20}$ Mitchell V. Charnley, “Preliminary Notes,” 399

${ }^{21}$ Fred Berry, “A Study of Accuracy,” 490

${ }^{22}$ Ibid.
} 
Looking solely at subjective errors, Lawrence and Grey set out to find the causes of such errors and offer ways to avoid them. ${ }^{23}$ Because of the focus on only subjective errors, the sample size for this study is rather small. Of the 140 surveys sent to news sources, 82 were returned, but only 21 were viable for the study. ${ }^{24}$ Following a different route than prior scholars, Lawrence and Grey conducted 19 in-depth interviews with news sources and 16 with the reporters who wrote the stories. ${ }^{25}$ Reporters and news sources often differed on the causes of the inaccuracies. News sources cited “sensationalism and lack of personal contact” as reasons for the inaccuracies. ${ }^{26}$ Returning to the idea of individual and organizational routines, the reporters blamed time demands along with problems in news desk practices and policies. ${ }^{27}$

Newspaper credibility has been the subject of research for such scholars as Philip Meyer, Tony Rimmer and David Weaver, and Cecilie Graziano and Kristin McGrath. The scale for measuring media credibility has evolved over time. A four-factor scale for media credibility developed by Jacobson ${ }^{28}$ developed into a 12 -factor scale used by Graziano and then dwindled to a five-factor developed by Meyer. In developing the 12factor scale, Graziano used a factor analysis of the 16 items used to measure peoples' attitude toward newspapers. After the factor analysis, 12 of the items were grouped

\footnotetext{
${ }^{23}$ Gary C. Lawrence and David L. Grey, “Subjective Inaccuracies in Local News Reporting,” Journalism Quarterly 46 (winter 1969): 753-57

${ }^{24}$ Ibid., 754

${ }^{25}$ Ibid.

${ }^{26}$ Ibid., 755

${ }^{27}$ Ibid.

${ }^{28}$ Raymond S.H. Lee, “Credibility of Newspaper and TV News,” Journalism Quarterly 55 (summer 1978): 282, Harvey K. Jacobson, “Mass Media Believability: A Study of Receiver Judgments,” Journalism Quarterly 46 (spring 1969): 20-28
} 
together to create the scale. Those items grouped together included, are newspapers fair, unbiased, tell the whole story, are accurate, respect people’s interests, are concerned abut the community's well-being, separate fact and opinion, can be trusted, are concerned about the public interest, are factual, and have well-trained reporters. ${ }^{29}$ Meyer then used this grouping to create a smaller scale for measuring credibility: are newspapers fairunfair, unbiased-biased, tell the whole story - doesn't tell the whole story, accurateinaccurate, can be trusted-can’t be trusted. ${ }^{30}$

The credibility of newspapers has been researched in great detail since the early 1980’s with varying results on the severe nature of the topic. Philip Meyer designed a five-item index for which to measure the credibility of newspapers. He noted, although there is a growing interest in the topic of media credibility, there isn’t one definition scholars can agree on. ${ }^{31}$

The American Society of Newspapers conducted several surveys regarding the credibility of the media in 1985. By far, this study has had the most comprehensive look at the issue. ${ }^{32}$ Having two phases, including focus groups, the ASNE interviewed 1,600 adults. At the completion of the second phase 1,002 (or 63\%) had participated in both phases. ${ }^{33}$ When comparing newspapers and television, ASNE found their believability ratings to be relatively equal; however, newspapers faired better with regard to local

\footnotetext{
${ }^{29}$ Cecilie Graziano and Kristin McGrath, “Measuring the Concept of Credibility,” Journalism Quarterly 63 (autumn 1986): 454

${ }^{30}$ Philip Meyer, “Defining and Measuring Credibility Of Newspapers: Developing and Index,” Journalism Quarterly 65 (fall 1988): 574

${ }^{31}$ Ibid., 567

${ }^{32}$ Cecilie Graziano and Kristin McGrath, "Measuring the Concept of Credibility,” 452

${ }^{33}$ Ibid., 453
} 
news. ${ }^{34}$ The researchers did note under representations of some groups such as: people aged 18-24 and 65-older, men and people with lower levels of education and over representation of groups such as: women, married persons and those aged 25-44. ${ }^{35}$

Rimmer and Weaver conducted a study to determine if different style questions lead to different answers of credibility. ${ }^{36}$ Previous studies had found there to be no correlation between media use and media credibility, but Rimmer and Weaver noted that when

“one moves from behavioral measures of media use, such as the 'read yesterday' or 'viewed yesterday' questions, to more affective measures such as the 'most preferred' medium questions, one is likely to find some correlation, although weak, between media use and media credibility." 37

Focusing only on local news, which according to the ASNE's study newspapers faired better on, Abel and Wirth hypothesized that television news in times of conflicting reports, when the information differs between media outlets, would be better believed than newspapers. ${ }^{38}$ The researchers surveyed 681 adults in the Detroit area, but only used those who read a newspaper and watched television news in their data. Proving their hypothesis correct, Abel and Wirth found $43 \%$ of respondents believed television over newspapers in presenting local news. ${ }^{39}$ The questionnaires did include open and closed

\footnotetext{
${ }^{34}$ Ibid., 462

${ }^{35}$ Ibid., 453

${ }^{36}$ Tony Rimmer and David Weaver, "Different Questions, Different Answers? Media Use and Media Credibility,” Journalism Quarterly 64 (1987): 30

${ }^{37}$ Ibid., 32

${ }^{38}$ John D. Abel and Michael O. Wirth, “Newspaper vs. TV Credibility for Local News,” Journalism Quarterly 54 (1977): 372

${ }^{39}$ Ibid., 373
} 
ended questions; however, the researchers only tested one geographic area. The area of Detroit may not be a true representation of the perceptions of local news in other areas.

Graziano attempted to establish if the credibility crisis really existed in 1985 by examining four prior credibility studies, one of which was the ASNE study mentioned above. The other three studies included Times Mirror, the Gannett Center for Media Studies and the Los Angeles Times. ${ }^{40}$ These studies, all launched in the same year, produced seven areas of consistency, but also several areas of inconsistency. The seven areas of consistency, where consistency is the items that are found dominant across all the studies, included - attitudes toward bias, too much coverage of "bad news," how the media treat certain groups, media treatment of the average person, the media as a watchdog over government, and the kinds of people most critical of the media.

Most appropriate is the inconsistency found regarding accuracy. The Gannett Center, ASNE and Times Mirror studies all found about half of the respondents gave high ratings of accuracy, but the L.A. Times found a smaller portion. ${ }^{41}$ Graziano said that the wording of the questions, either positive or negative, could be to blame for the difference in findings citing that people tend to rate the media accurate when questions are phrased positively. ${ }^{42}$ Overall, when comparing those four surveys, the credibility crisis wasn't found to be too big of a concern; however, it was found that the public does not believe everything it sees in the media. ${ }^{43}$ But, "such skepticism is not necessarily bad; there can be dangers in uncritical acceptance of media fare., ${ }^{44}$

\footnotetext{
${ }^{40}$ Cecilie Graziano, “How Credible Is the Credibility Crisis?” Journalism Quarterly 63 (autumn 1986): 272

${ }^{41}$ Ibid., 273

${ }^{42}$ Ibid.

${ }^{43}$ Ibid., 278

${ }^{44}$ Ibid.
} 
Albert C. Gunther argued that the idea of media credibility is a matter of receiver (or reader) interpretations and personal involvement in situations or groups, not characteristics of the source (or reporter). ${ }^{45}$ Using the data gathered from the 1985 ASNE survey, Gunther found that those who were directly related to a situation or group were more likely to scrutinize a story and increase the likelihood of taking a skeptical view. ${ }^{46}$

Loss of accuracy within print media has been viewed as one of the reasons newspapers have lost credibility. Ariel Hart, a free-lance fact-checker for the Columbia Journalism Review, wrote that she had never fact-checked a story that didn't have any mistakes. ${ }^{47}$ One scholar admitted that newspapers should possibly be published with this warning label:

“The concepts of today's newspaper should be treated with care. The information collected and presented was done so under circumstances and conditions that, history has shown, are error prone..."48

Lack of time in the news gathering/writing process, the amount of information to sort through, and the need to produce stories understandable to readers are all reasons given for inaccuracies in stories. ${ }^{49}$ Several of the studies break the stories used into two categories; spot and anticipated news stories. ${ }^{50}$ "Spot" stories are those that are

\footnotetext{
${ }^{45}$ Albert C. Gunther, "Biased Press Or Biased Public? Attitudes Toward Media Coverage of Social Groups,” Public Opinion Quarterly 56 (1992): 158

${ }^{46}$ Ibid., 161

${ }^{47}$ Ariel Hart, “Delusions Of Accuracy,” Columbia Journalism Review 42 (Jul/Aug 2003): 20

${ }^{48}$ Herb Strentz, “Universal Ethical Standards,” Journal of Mass Media Ethics 17 (4): 269

${ }^{49}$ Fred C. Berry, “A Study of Accuracy in Local News Stories of Three Dailies,” Journalism Quarterly 44 (1967): 482

${ }^{50}$ Ibid.,484
} 
unforeseen such as fires and accidents while "anticipated" stories are those that are known about in advance such as a meeting. ${ }^{51}$

Several studies have shown that editorial policies differ in the aspects of what constitutes an error as well as how to acknowledge and correct them. Scholar Steve M. Barkin and Mark R. Levy stated:

"Leaders of the newspaper industry, among others, have contended that correction notices are part of a larger effort to improve that medium's credibility."52

Media scholar D. Charles Whitney conducted a study on the link between correction policies and corrections in 12 U.S. newspapers. Six of the papers were national dailies and six smaller dailies. He concluded - that the number of corrections was related to the size of the publication, that reporters and staff members spotted more than half of the corrected errors, and that objective errors were corrected most often. ${ }^{53}$ Whitney contends:

“...nothing is more crucial to a news organization than its reputation for accuracy and that nothing is more crucial to establishing this reputation than the honest, timely and public admissions of errors." 54

However, Whitney also notes that readers are more concerned with the "subjective" type errors, but newspapers are more concerned with “objective” ones and tend to correct them more often.

Whitney also found that "most papers are correcting their errors when they find them, and most have policies of correcting them in fixed places in the paper under

\footnotetext{
51 Ibid.

52 Steve M. Barkin and Mark R. Levy, “All the News That's Fit To Correct: Corrections in the Times and the Post,” Journalism Quarterly, 60 (Summer 1983): 220

53 D. Charles Whitney, "Beggin your pardon. Corrections and corrections policies at twelve US newspapers,” New York Gannett Center for Media Studies, (1986): 8

54 Ibid.
} 
standing headlines, making them accessible to readers.” ${ }^{55}$ He also makes the suggestion that papers would benefit from putting their correction policies in writing:

"For if corrections are to promote accountability, a paper's policy must be known to anyone on the paper in a position to make an error and to anyone outside the paper who seeks a correction or clarification"56

Fowler and Mumert wanted to provide insight into the correction policies of newspapers that represent a greater percentage of the publishing industry, thus a sample was drawn from Arkansas - a sample which has a ratio of weekly to daily newspapers not totally dissimilar to the national ratio. ${ }^{57}$ The duo mailed questionnaires to 35 daily and 102 weekly newspapers in the state with a stamped, self-addressed envelope accompanying the survey. ${ }^{58}$ A cover letter explained the nature of the survey and was addressed to the publisher with the request that he/she pass it along to a staff member who deals with corrections on a regular basis. $^{59}$

Seventy of the 135 newspapers returned the surveys for a response rate of $51.8 \%$ and all but one of the papers reported publishing corrections. ${ }^{60}$ Of the 49 respondents to report having a correction policy, 17 of them reported having written policies. ${ }^{61}$ Through their survey responses, Fowler and Mumert concluded that the newspapers had little hesitation when it came to publishing corrections; weeklies were less likely to reserve a

\footnotetext{
${ }^{55}$ Ibid., 9

${ }^{56}$ Ibid., 12

${ }^{57}$ Gilbert L. Fowler and Tommy L. Mumert, "A Survey of Correction Policies of Arkansas Newspapers,” Journalism Quarterly, 65 (Winter 1988): 854

${ }^{58}$ Ibid., 855.

${ }^{59}$ Ibid.

${ }^{60}$ Ibid.

${ }^{61}$ Ibid.
} 
standard spot for a correction and none of the papers "indicated a likelihood toward correcting errors concerning overemphasis or underemphasis - subjective-type errors.”,

Throughout the span of 30 years, studies on accuracy have produced relatively the same results. Errors in meaning have been the most commonly found mistakes. While the number of stories tested has varied, all have found the media to be fairly accurate.

However, in 2002 Scott Maier found that:

"while accuracy and credibility have become buzzwords in the news industry, the research literature is surprisingly devoid of recent studies of errors in newspapers ... it has been more than a decade since the last published peer-reviewed research assessed the rate and types of errors made in daily newspapers.”63

Maier hoped to find what types of errors occur most often and which were considered most important and the relationship between the rate of errors and the credibility of a newspaper. ${ }^{64}$ Of the 553 local stories published over a 31-day period, Maier identified 1,013 news sources. From those 1,013 news sources, 946 surveys were mailed and 504 were returned. Unlike previous studies where more stories were found to be accurate, Maier found fifty-two percent of the respondents found at least one error in a story with more factual errors than subjective ones. ${ }^{65}$ Using Meyers’ five-item believability index of bias, trustworthiness, accuracy, fairness and “tells the whole story,” there was a moderately strong connection between errors and story credibility, but not with the credibility of the entire paper. ${ }^{66}$

\footnotetext{
${ }^{62}$ Ibid., 858

${ }^{63}$ Scott Maier, “Getting It Right? Not in 59 Percent of Stories,” Newspaper Research Journal 23 (winter 2002): 10-11

${ }^{64}$ Ibid., 13

${ }^{65}$ Ibid., 15

${ }^{66}$ Ibid., 18
} 
Attempting to tackle the accuracy and credibility problem of newspapers, the American Society of Newspaper Editors conducted a study in 1999 that didn’t simply focus on the "news source." ASNE, wanting to know what reasons were believed to be the source of the credibility issues, conducted focus groups with readers and interviewed journalists as well. Both groups, readers and journalists, agreed that deadline pressures were viewed as one of the major causes of published errors; however, one-third of journalists and 27 percent of readers noted sloppiness and laziness as sources of the problem as well. ${ }^{67}$ In fact in 2002, two-thirds of the nation's journalists received no regular skills training at all. ${ }^{68}$ When papers are published with errors in them usually corrections follow; however, only 19 percent of readers said they "always” saw corrections as opposed to the 40 percent who only "sometimes" saw them. ${ }^{69}$ A much higher percentage of journalists, 58 percent, said they "always" saw corrections. ${ }^{70}$

With regard to the belief that "the major job of the press is to report the truth, even if it's painful or shocking to a lot of people,” an overwhelming majority of readers have become more skeptical about accuracy and believe newspapers run stories without fact-checking them just because another paper did (73 and 68 percent respectively). 52 percent of newsrooms agree. ${ }^{71}$ Christine Urban wrote:

"The foundation of journalistic credibility is accuracy, and when readers find factual errors or spelling and grammar mistakes they make judgments about our

\footnotetext{
${ }^{67}$ American Society of Newspaper Editors, “Building Reader Credibility,: available from http://www.asne.org/index.cfm?id=3726; Internet, accessed 23 January 2004

${ }^{68}$ Geneva Overholser, “Careening Toward Extinction With Salvation Firmly in Hand,” Columbia Journalism Review 41 (Sept/Oct 2002): 75

${ }^{69}$ American Society of Newspaper Editors, "Building Reader Credibility,: available from http://www.asne.org/index.cfm?id=3726; Internet, accessed 23 January 2004

${ }^{70}$ Ibid.

${ }^{71}$ Ibid.
} 
competence ... the simple existence of corrections boxes and reader advocates sends the right signals of editorial recognition, concern and attention to the problem.",72

Building on the idea of reader advocates noted by Urban, would it be ideal for newspapers to employ ombudsmen to tackle reader concerns? In lieu of the Jayson Blair scandal, the Associated Press Managing Editors performed an informal survey of readers to determine why inaccuracies go unreported. ${ }^{73}$ Doubts about the interest of the newspaper and not knowing whom to contact were the reasons behind not reporting inaccuracies. $^{74}$

Although study after study show a steady rate of credibility and accuracy dilemmas, newspapers have not hired ombudsmen for financial reasons and some, such as The New York Times, holding that the newspaper itself should validate reasoning's behind its choices. ${ }^{75}$ American Journalism Review's editor and senior vice president, Rem Rieder contends hiring an ombudsman would be ideal for the Times to regain credibility. $^{76}$

Ombudsmen offer a port for readers to vent when issues arise, but how they effect the decisions journalists make is important. David Pritchard hypothesized that journalists will be more likely to "express greater ethical caution” and "have a more positive view of how well their newspaper informs the public” if their newspaper has an ombudsman. ${ }^{77}$

\footnotetext{
${ }^{72}$ Ibid.

${ }^{73}$ Nat Hentoff, “A Few Good Ombuds.,” Editor and Publisher 136 (27): 30

${ }^{74}$ Ibid., 30

${ }^{75}$ Josh Getlin, “Ombudsman: Monitoring Yourself,” Columbia Journalism Review 38 (March/April 2000): 51

${ }^{76}$ Rem Rieder, “Wanted: One Good Ombudsman,” American Journalism Review 25 (Aug/Sept 2003): 1
} 
Four hundred and sixty-two journalists from daily newspapers were surveyed on newsgathering techniques and how well their newspapers informed the public. ${ }^{78}$ Of those journalists, 89 worked for newspapers that had ombudsmen. The first hypothesis was rejected. The presence of an ombudsman did not have an effect on journalists' views of controversial news techniques; however, the presence of an ombudsman did affect the journalists’ view of how well their newspaper informed the public. ${ }^{79}$

Although the position of the ombudsman may look good from a reader's point of view, the position is not effective within the newsroom because reporters have tremendous autonomy and tend to make decisions on a case-by-case basis, ${ }^{80}$ and because the cultural norms of newspapers are too deeply imbedded. ${ }^{81}$ Christopher Meyers contends that if the position of the ombudsman is necessary for newspapers to regain credibility, they cannot be an “insider” (or former journalist) and they must have the authority to reward and punish. ${ }^{82}$

Along with the idea of employing an ombudsman, news councils, established to resolve public complaints against the news media, are one of the options researched to possibly curve credibility upward. The National News Council, established in 1973, was

\footnotetext{
${ }^{77}$ David Pritchard, “The Impact of Newspaper Ombudsmen on Journalists’ Attitudes,” Journalism Quarterly 70 (spring 1993): 81

${ }^{78}$ Ibid.

${ }^{79}$ Ibid., 84

${ }^{80}$ David Pritchard, “The Impact of Newspaper Ombudsmen,” 82

${ }^{81}$ Ibid.

${ }^{82}$ Christopher Meyers, "Creating an Effective Newspaper Ombudsman Position,” Journal of Mass Media Ethics 15 (4): 248-256
} 
the first council to be formed in the United States; however, the council disintegrated in 1984 due to insufficient funds and media cooperation. ${ }^{83}$

The Minnesota News Council, today, is one of the only news councils in the nation. ${ }^{84}$ Recognizing the interest in news councils is fueled by the declining credibility, ${ }^{85}$ Ugland and Breslin seek to find if the MNC “can serve as a useful vehicle for defining journalism ethics.”86 Two assumptions were noted at the beginning of the study. News councils cannot improve the credibility of journalists unless it has moral authority and they cannot have moral authority unless they are deemed legitimate by both the public and journalists. ${ }^{87}$

Analyzing the content of the 125 rulings of the council for principles and precedent, the researchers found seventy-six percent of the cases contained a statement of principle but they lacked specificity and the researchers theorized that the legitimacy of the council could suffer. ${ }^{88}$ The researchers asked the question, "Does the Council refer to its pervious determinations in making rulings?”89 Of the 125 determinations rendered by the council, only two referred to any of the earlier cases. ${ }^{90}$ Through this, the researchers

\footnotetext{
${ }^{83}$ Alicia C. Shepard, “Going Public,” American Journalism Review 19 (April 1997): 26

${ }^{84}$ Erik Forde Ugland and Jack Breslin, "Minnesota News Council: Principles, Precedent, and Moral Authority,” Journal of Mass Media Ethics 15 (4): 232

${ }^{85}$ Ibid., 233

${ }^{86}$ Ibid.

${ }^{87}$ Ibid., 234

${ }^{88}$ Ibid., 246

${ }^{89}$ Ibid., 242

90 Ibid.
} 
concluded that the council paid little attention to its past decisions, which could raise fear that its rulings were only temporary. ${ }^{91}$

In 1981, Robert Schafer devoted time to exploring how the Minnesota News Council developed standards of ethics. The council had been established ten years prior to the study; therefore, creating a sample size of only 42 cases. In regard to accuracy cases taken on by the council,

"The council has asserted that accusations in a news story should be checked with principals involved so they can respond, that errors should be corrected promptly and that checking on complaints of inaccuracy should be an obligation of a newspaper.",92

In response to corrections that took an abnormally long time to appear (55 days), Schafer found the council did not offer specific guidelines, but offered statements of their tardiness and inadequacy. ${ }^{93}$ Overall, the council has not developed guidelines for journalists in any particular area of ethics. ${ }^{94}$

Although these studies have pointed toward the inadequacy of the MNC, in the wake of credibility issues, the forming of news councils has garnered support from wellknown journalists. Mike Wallace, who spent 18 weeks in trial defending his 1982 Westmoreland documentary, is an avid supporter of news councils. ${ }^{95}$ Supporters and dissenters of news councils do agree that one step toward solving the credibility problem is being more accountable. ${ }^{96}$

\footnotetext{
${ }^{91}$ Ibid., 246

${ }^{92}$ Ibid., 358

${ }^{93}$ Ibid.

${ }^{94}$ Ibid., 361

${ }^{95}$ Shepard, Going Places, 25

${ }^{96}$ Ibid., 26
} 
“As society’s mores evolve, the guidelines journalists use to govern themselves are changing as well. But some decisions invited disdain and anger from the public, who now rank journalists right up there with lawyers and used car salesmen."97 When editors explain their reasoning behind running controversial stories or photos it stands to reason that readers will respect the decision - even if they aren’t in agreement with it.

In an interview with Paterno, Michael Josephson notes that some journalists believe that if controversial decisions are acknowledged then credibility is destroyed, but he has found the public disagrees and views arrogance as detrimental to credibility. ${ }^{98}$ Jerry Roberts, managing editor for the San Francisco Chronicle, views that explaining too much becomes a danger, cover your ass device. ${ }^{99}$ But, non-journalists believe the media should be held accountable for their actions. ${ }^{100}$

There are several other aspects in the realm of journalism that could have had an effect on the loss of credibility and accuracy over the years. The copy-editing desk has undergone changes over the years. Copy editors now have computers to aide in their editing process and are now undertaking more jobs that divert their attention from copyediting. These changes have been implemented in the attempt to improve the process and to break down walls between reporters, editors and designers. ${ }^{101}$ Since lack of accuracy, as found in the studies presented in this paper, is one of the major causes of declining credibility, will these news measures be effective? Proponents of eliminating the position

\footnotetext{
97 Susan Paterno, “I Can Explain,” American Journalism Review 20 (July/Aug 1998): 25

98 Ibid., 26

99 Ibid., 27

${ }^{100}$ Penny Pagano, "Public Perspectives On The Press,” American Journalism Review 15 (December 1993): 41

101 John Russial, “Goodbye copy desks, hello trouble?” Newspaper Research Journal 19 (spring 1998): 2
} 
argue that copy-editing will not be eliminated, but reporters should be able to write copy that is error free. ${ }^{102}$ Several newspapers have removed copy desks and moved their copy editors onto reporting teams. One example is the Wichita Eagle. With the elimination of its copy desk, the number of typos and grammatical errors increased initially. ${ }^{103}$

Journalists follow codes of ethics, but there isn’t one set for them to follow. No two situations within the field of journalism are exactly alike. Newspapers rely loosely on codes of ethics from the ASNE and Society of Professional Journalists, but the vagueness of these codes is noted. ${ }^{104}$ For example, the ASNE Code of Ethics in Article IV states,

"Every effort must be made to assure that the news content is accurate, free from bias and in context, and that all sides are presented fairly," and "Significant errors of fact, as well as errors of omission, should be corrected promptly and prominently."105

The Society of Professional Journalists offer more specific guidelines for journalists,

"Test the accuracy of information from all sources and exercise care to avoid inadvertent error. Deliberate distortion is never permissible," and "Never plagiarize."

As found through gatekeeping and hierarchy studies, journalists rely on intrinsic and extrinsic motivations to make decisions. When making ethical decisions, they often rely on their own instincts, refer to their paper's codes (if it has a set), or have conversations with their editors. ${ }^{107}$ But how do these stand up against public perception?

\footnotetext{
${ }^{102}$ Ibid., 17

103 Ibid., 20

${ }^{104}$ Alicia C. Shepard, “Legislating Ethics,” American Journalism Review 16 (Jan/Feb 1994): 38

105 American Society Of Newspaper Editors, Codes of Ethics, available from http://www.asne.org/kiosk/archive/principl.htm; Internet, accessed 28 January 2004

${ }^{106}$ Society of Professional Journalists, Codes of Ethics, available from http://www.spj.org/ethics_code.asp; Internet, accessed 28 January 2004

107 Alicia Shepard, “Legislating Ethics,” 36
} 
Sandra Braman chose four codes of ethics, two from print and two from broadcast, to analyze complaints brought before the National News Council. The council was formed in 1973 to provide a means for complaints against the press to be heard and investigated by a council comprised of both the public and press. ${ }^{108}$ Comparison of ethical measures suggested by the complainants in original complaints filed with the National News Council and the codes was conducted. ${ }^{109}$ Of the 180 standards found common between the complaints and codes, standards pertaining to facticity were the most common with "be factually accurate" garnering 53 citations. ${ }^{110}$ Braman found three substantial differences between the views of the audience and the media. First, the pubic believes "there is a fixed body of facts that comprises either 'a story' or 'the news.”' Second, the public attributes "intention to inaccuracy or omission of facts" more so than the media. For example, the members of the public set a standard like “don't lie” while the media prefer “don’t fictionalize."111 Lastly the public, in regard to corrections, has more specific criteria in mind than the media does. For example, the public feel that sources should be identified and corrections should hold the same weight and placement as the original story. ${ }^{112}$ With these findings, it appears that the media remaining generalists is one of the leading causes of credibility being called into question. ${ }^{113}$

\footnotetext{
${ }^{108}$ Sandra Braman, "Public Expectations of Media Versus Standards in Codes of Ethics,” Journalism Quarterly 62 (winter 1985): 72 
Newspaper readers find mistakes, but don’t know who to report them to or even if the newspaper will care. Accuracy, as found by the studies in this literature review, has been attributed to the decline in credibility. Several options were discussed to help swing credibility upward. News councils and ombudsmen give readers an established way to address their concerns, but there were several flaws in both systems. Responses from news councils lacked specific directions for addressing issues such as corrections and omissions, while ombudsmen served as public relations officers, established routines and hierarchies within a newspaper did not allow them to invoke change. Working to correct accuracy problems should be a step in the right direction to fixing the credibility problems. 


\section{CHAPTER 3}

\section{HYPOTHESES}

$\mathrm{H}_{1}$ : Objective errors, which are defined as errors in names and titles, time, place, numbers, date, and age, will be the most commonly corrected type of error.

$\mathrm{H}_{2}$ : Smaller circulation papers are less likely to have a written, published correction policy.

$\mathrm{H}_{3}$ : When surveyed, newspaper editors will say objective errors occur most often in their publications.

$\mathrm{H}_{4}$ : A majority of publications will have a standard place within the newspaper where readers can find corrections.

\section{METHODOLOGY}

Much of previous research has focused on determining the accuracy of newspaper stories and used questionnaires sent to news sources to find inaccuracies within stories. Charnley first developed categories for which to separate the types of errors found in news stories. In his 1916 study, Charnley classified three different errors: mechanical or typographical; writer’s errors which included names, titles, ages, addresses, places, times, dates, quotations, and grammar and spelling; and errors in meaning. ${ }^{114}$ However, Whitney, Fowler and Mumert explored the idea of how newspapers deal with corrections and the relationship between correction policies and printed corrections.

In order to answer the four research questions listed above, the researcher intends to use a methodology similar to that of Fowler and Mumert. She interviewed the editors, or the person directly responsible for making decisions regarding corrections on a daily basis, of all West Virginia daily newspapers. There were a total of 20 daily newspapers in

\footnotetext{
${ }^{114}$ Mitchell V. Charnley, “Preliminary Notes,” 396
} 
the state. The researcher attempted to contact all of the editors of the daily newspapers via telephone. The researcher discussed her research with each editor and asked for his/her participation in a small survey. The editors that were willing to participate were provided operational definitions of a "correction," “objective errors” and "subjective errors." “Correction” is operationally defined as an omission of a mistake made by the newspaper. “Objective errors” were defined as errors in names and titles, time, place, numbers, date, and age. "Subjective errors” were defined as errors in omission, misquotation or misattribution. A list of the questions is listed below:

1. Does your publication have a correction policy?

a. If yes, is it a written policy?

b. If no, how does your publication handle corrections when errors occur?

2. Is the policy featured in your publication daily?

3. Is it located in the same place each time it is featured?

4. What kinds of errors occur most often in your publication?

5. How do you and/or your staff decide what type of errors need a printed correction?

6. Are writers penalized for having errors in their stories?

7. How long has the policy existed?

8. What prompted its creation?

The research also analyzed the corrections found in all 20 daily newspapers for a 60day time period (Dec. 1, 2004 - Jan. 29, 2005). When analyzing the corrections, the researcher looked for three things. First, how many corrections were printed in the last 60 days? Second, what type of error - objective or subjective - was corrected most often? Third, was the error attributed?

A pilot study was conducted last semester using Charnley’s established categories of subjective and objective errors. The researcher used one year's worth of corrections 
printed in West Virginia’s largest daily newspaper, The Charleston Gazette. The types of errors established by printed corrections were divided into two categories: objective and subjective. These two categories were then broken down into subcategories. The subcategories formed under objective errors include: time, date, place, spelling, name/title, numbers, grammar and other. Other is used when the correction does not fall into any of the above categories. The subcategory "numbers" includes misstatement of telephone numbers or numerical amounts. Subcategories under subjective errors include: misattribution, misquotations and omission. Misattribution is used when statements within a news story, direct quotes or not, are attributed to the wrong source. Misquotation is used when a news source is quoted and words or phrases within the quotations are not accurate. Omission is used when important information, relevant to the meaning of the story, is left out. Also included in these categories is who is to blame for the error: editor, reporter, and source or unidentified. Unidentified is only used when the correction does not specifically name any of the three previously mentioned persons as the cause of the error.

Although all of the corrections obtained for the pilot study were obtained from the paper's online library, not all of the daily newspapers keep an online archive. For those newspapers where corrections could not be obtained through an online archive, they were obtained through an archive at a library. All data was complied for an overall picture of how West Virginia daily newspapers handle corrections.

The researcher also analyzed the correction policy of those newspapers that have them printed in their publication. The policies were separated by circulation as well as similarities and differences. The placement of the policy in the newspapers was also noted. 


\section{CHAPTER 4}

\section{RESULTS AND DISCUSSION}

In order to assess hypothesis one, the researcher collected corrections from 16 of West Virginia’s 18 daily newspapers. The researcher did not find any printed corrections in two of the 18 newspapers during the chosen 60-day time period. A total of 151 corrections were collected from the 18 papers (see table 1).

Table 1. Total Number of Errors in Newspapers

\begin{tabular}{|c|c|c|}
\hline $\begin{array}{c}\text { Type of error } \\
\text { corrected }\end{array}$ & $\begin{array}{c}\text { Total } \\
\text { number } \\
\text { corrected }\end{array}$ & $\begin{array}{c}\text { Valid } \\
\text { Percent }\end{array}$ \\
\hline $\begin{array}{c}\text { Objective } \\
\text { Subjective }\end{array}$ & 117 & 77.5 \\
\hline
\end{tabular}

Hypothesis one states: “Objective errors, which are defined as errors in names and titles, time, place, numbers, date, and age, will be the most commonly corrected type of error.” As can be seen in table 1, of the 151 errors, 117 of them were objective. Therefore, hypothesis one is accepted.

Table 2 (shown below) breaks the results into how many errors were found in each newspaper. 
Table 2. Total Number of Corrections in Each Newspaper

\begin{tabular}{|c|c|c|}
\hline Newspaper & Frequency & Percent \\
\hline Dominion Post & 28 & 18.5 \\
\hline Charleston Gazette & 17 & 11.3 \\
\hline Weirton Daily Times & 13 & 8.6 \\
\hline Clarksburg Exponent Telegram & 11 & 7.3 \\
\hline Wheeling Intelligencer & 10 & 6.6 \\
\hline Parkersburg News and Sentinel & 9 & 5.9 \\
\hline The Herald-Dispatch & 9 & 5.9 \\
\hline Bluefield Daily Telegraph & 8 & 5.3 \\
\hline Wheeling News Register & 8 & 5.3 \\
\hline Elkins Inter-Mountain & 7 & 4.6 \\
\hline Charleston Daily Mail & 7 & 4.6 \\
\hline Beckley Register-Herald & 6 & 3.9 \\
\hline Fairmont Times & 6 & 3.9 \\
\hline Martinsburg Journal & 5 & 3.3 \\
\hline Williamson Daily News & 5 & 3.3 \\
\hline Mineral Daily News Tribune & 1 & .6 \\
\hline Wayne County News & 1 & .6 \\
\hline
\end{tabular}

As shown, The Dominion Post and The Charleston Gazette - two of the highest circulating newspapers in the state - had the most printed corrections during the 60-day time period. The Mineral Daily News-Tribune and Wayne County News each had the lowest number of corrections with one each.

For the purposes of this study, 15,500 was used as the dividing line between high and low circulating newspapers. Circulation numbers for the daily newspapers were obtained from the 2003 West Virginia Media Guide. The newspapers listed in Tables 3 and 4 our ranked highest to lowest by circulation, not by the number of errors corrected in the 60-day time period.

A Pearson Chi Squared test was performed in order to test the validity of the above results. In order to be considered statistically valid, a P-value of .05 or less should be returned. For these results, the test returned a P-value of .867; therefore, the results 
cannot be considered statistically valid. However, it should be noted that the sample size was less than 200 and this could be a factor in the value the test returned.

As shown in the tables below, with the exception of The Charleston Gazette and the Dominion Post, most of the newspapers are close with the number of corrected errors that was found in the 60-day time period. Those newspapers whose circulation was below 5,000 (Mineral Daily News Tribune, Moundsville Daily Echo and Wayne County News) were the only publications where 0-1 errors were found. Although D. Charles Whitney concluded that the number of corrections was related to the size of the publication, ${ }^{115}$ the results shown in the tables above cannot accurately conclude that is the same for West Virginia’s daily newspapers.

Table 3. Breakdown in the Amount of Errors in High Circulating Daily Newspapers $(15,500+)$

\begin{tabular}{|c|rrr|}
\cline { 2 - 4 } Newspaper & Circulation & $\begin{array}{c}\text { Number } \\
\text { of } \\
\text { Errors }\end{array}$ & Percent \\
\hline Charleston Gazette & 53,307 & 17 & 11.3 \\
Charleston Daily Mail & 40,000 & 7 & 4.6 \\
The Herald-Dispatch & 36,856 & 9 & 5.9 \\
Beckley Register-Herald & 33,000 & 6 & 3.9 \\
Parkersburg News and & 26,833 & 9 & 5.9 \\
Sentinel & & & \\
Martinsburg Journal & 23,000 & 5 & 3.3 \\
Wheeling Intelligencer & 21,526 & 10 & 6.6 \\
Dominion Post & 21,500 & 28 & 18.5 \\
Wheeling News Register & 21,500 & 8 & 5.3 \\
Bluefield Daily Telegraph & 20,071 & 8 & 5.3 \\
Clarksburg Exponent & 20,000 & 11 & 7.3 \\
Telegram & & & \\
\hline
\end{tabular}

\footnotetext{
${ }^{115}$ D. Charles Whitney, "Begging your pardon. Corrections and corrections policies at twelve US newspapers": 8
} 
Table 4. Breakdown in the Amount of Errors in High Circulating Daily Newspapers (Below 15,500)

\begin{tabular}{|c|c|c|c|}
\hline Newspaper & Circulation & $\begin{array}{c}\text { Number } \\
\text { of } \\
\text { Errors }\end{array}$ & Percent \\
\hline Fairmont Times & 13,850 & 6 & 3.9 \\
\hline Elkins Inter-Mountain & 10,800 & 7 & 4.6 \\
\hline Williamson Daily News & 10,500 & 5 & 3.3 \\
\hline Weirton Daily Times & 7,486 & 13 & 8.6 \\
\hline Mineral Daily News Tribune & 4,500 & 1 & 0.6 \\
\hline Moundsville Daily Echo & 4,000 & 0 & 0 \\
\hline Wayne County News & 3,089 & 1 & 0.6 \\
\hline
\end{tabular}

When viewing the data above, several questions that can be used for future research are raised. Were the corrections found spotted by reporters and staff members at the publications, or were they all found by readers? Do editorial policies affect the type (objective or subjective) and number of errors that are corrected?

The following tables (5, 6 and 7) break down the types of errors - objective and subjective - into subcategories and the frequency that each occurred in the newspapers over the 60-day period. As can be seen in table 5, the subcategory of error in a person's “name/title” was the most common objective error. The second most commonly found type of objective error was an error in "number” within a story. Finally, the third most common objective error was “other.” The “other” subcategory was defined as any correction of an error that did not fit any other subcategory. The unusually high number of “other" corrections is attributed to the newspapers not correcting an error, but clarifying information within a story. The researcher found that several newspapers sought to clarify that two people with the same name were not the same person. 
Table 5. Types of Objective Errors Corrected

\begin{tabular}{|lrr|}
\hline $\begin{array}{c}\text { Type of Objective } \\
\text { Error }\end{array}$ & & \\
Name/Title & Frequency & Percent \\
Number & 39 & 33.3 \\
Other & 24 & 20.5 \\
Date & 19 & 16.2 \\
Place & 13 & 11.1 \\
Time & 12 & 10.3 \\
Age & 4 & 3.4 \\
Grammar & 2 & 1.7 \\
Spelling & 2 & 1.7 \\
& 2 & 1.7 \\
\hline
\end{tabular}

The above results also fall in line with studies done by Charnley, Brown, Berry and Whitney. As stated in the literature review, all of these scholars found newspapers correct “objective” errors the most often with those errors in names and titles occurring most often. The same holds true for the corrections that appeared in West Virginia's daily newspapers over the 60-day time period used for this study.

Below, table 6 breaks down subjective error corrections into subcategories of misattribution, misquotation and omission. As can be seen by the frequency and the percentages, errors of omission were found to be corrected most often over the 60-day time period. A total of 19 corrections of omission were found, followed by nine corrections of misattribution and five of misquotation.

Table 6. Frequency of Subjective Errors Found

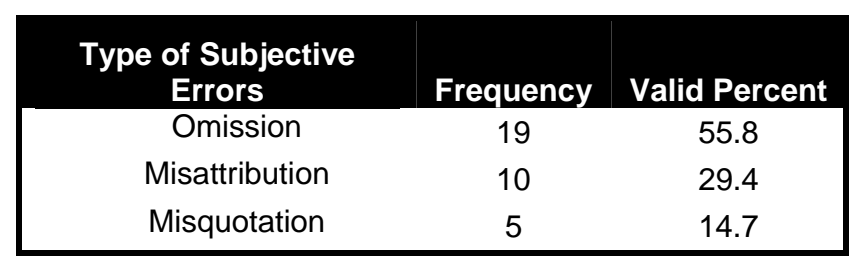

Table 7 shows who, in the correction, was cited as the cause of the error. The researcher found that almost all $-97.4 \%$ to be exact - of the corrections were not attributed to any one person. Only on four occasions did the researcher come across a 
correction where the error was attributed to either the editor or the source. None of the errors were attributed to a reporter.

Table 7. Frequency of Attributed Errors

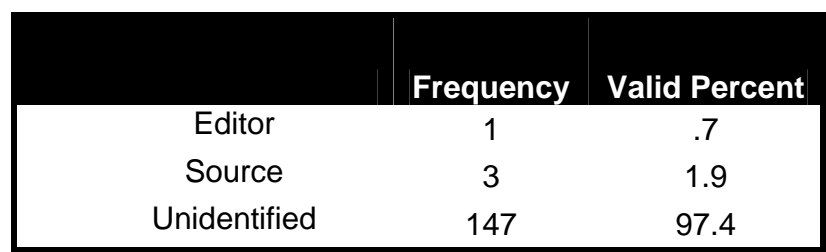

Comparatively, the pilot study and the final study produced similar results especially in the areas of type of error corrected and whom the error was attributed to. During the pilot study, of the 117 corrections used as the sample size, 78 of them were found to be corrections of objective errors, which constitute 66.7 percent of the corrections. The remaining 39 corrections, or 33.3 percent of the sample size, were found to be subjective.

The misidentification of a persons name or title was the most commonly found type of objective error. Thirty-six of the 117 corrections were correcting this type of misidentification. A correction printed on November 11, 2003 read, “Alice Click was misidentified in a Nov. 10 Gazette column. Click is no longer director of Concerned Women for America. She has not held that post for about two years."116 This is an example of misidentification of a person's title. The next highest amount of objective corrections with 13, or 11.1 percent, was correcting an error in numbers. This included correcting telephone numbers as well as dollar amounts. For example, a correction printed on June 17, 2003 read, “An incorrect telephone number was listed for the

${ }^{116}$ The Charleston Gazette, Correction, available from http://library.cnpapers.com/cgibin/texis/search?uquery=correction\&pub=gz; Internet, accessed 14 April 2004 
conference Wednesday sponsored by the West Virginia Coalition Against Domestic

Violence. To register for the four-day conference, call 965-3552.”117

Errors from a source were the least commonly found type of error, with 8 of the 117 being attributed to them, but two of the other three options (editor and reporter) were relatively close in number. Errors from the editor were the next most common with nine being attributed to them, while errors by a reporter were next with 15 . An overwhelming number, 85, of the 117 corrections were not attributed to one specific person.

Table 8. Numbers and Percentages of Types of Errors Corrected

\begin{tabular}{|cc|c|} 
Type of Error & Occurrence & Percentage \\
\hline Name/Title & 36 & 30.7 \\
Misattribution & 26 & 22.2 \\
Number & 13 & 11.1 \\
Date & 10 & 8.5 \\
Omission & 9 & 7.6 \\
Other & 6 & 5.1 \\
Place & 5 & 4.2 \\
Time & 5 & 4.2 \\
Misquotation & 4 & 3.4 \\
Spelling & 3 & 2.6 \\
Grammar & 0 & 0 \\
Age & 0 & 0
\end{tabular}

The results of the two studies were identical in the type of errors that were most commonly found and in that almost all of the errors were left unattributed.

In order to assess hypothesis two - "Smaller circulation papers are less likely to have a written, published correction policy” - the researcher not only surveyed editors about their publications' corrections policies, but also obtained the actual policies from the publications when available. Before discussing the results and the table below, it should be noted that the researcher was only able to get in contact with 13 of the 18 daily

\footnotetext{
117 The Charleston Gazette, Correction, available from http://library.cnpapers.com/cgibin/texis/search?uquery=correction\&pub=gz; Internet, accessed 14 April 2004
} 
newspaper editors. Only those newspaper editors the researcher was able to survey are represented in the table below.

The newspapers have been ranked highest to lowest by circulation. The circulation numbers were obtained from the 2003 West Virginia Associated Press Media Guide. For the purposes of this study, the researcher designated 15,500 as the divider between high and low circulating daily newspapers. There were seven high and six low circulating newspapers. With regard to corrections policies and the publication of those policies, the 13 editors were asked three questions:

1. Does your publication have a written correction policy?

2. Is the policy featured in your publication daily?

3. Is it located in the same place each time it is featured?

Table 9. Newspaper Editors Responses to Questions One - Three

\begin{tabular}{|lccccc|}
\hline \multicolumn{1}{c}{ Newspaper Name } & Circulation & Question 1 & Question 2 & Question 3 \\
Charleston Gazette & & & & \\
Charleston Daily Mail & 53,307 & No & No & No \\
Huntington Herald-Dispatch & 40,000 & Yes & Yes & Yes \\
Beckley Register-Herald & 36,856 & Yes & Yes & Yes \\
Parkersburg News and Sentinel & 33,000 & Yes & No & No \\
Martinsburg Journal & 26,833 & No & No & No \\
Wheeling Intelligencer & 23,000 & No & No & No \\
Wheeling News Register & 21,256 & Yes & Yes & Yes \\
Elkins Inter-Mountain & 21,500 & Yes & Yes & Yes \\
Logan Banner & 10,800 & Yes & Yes & Yes \\
Weirton Daily Times & 10,000 & No & No & No \\
Moundsville Daily Echo & 7,486 & No & No & No \\
Wayne County News & 4,000 & No & No & No \\
\hline
\end{tabular}

In response to question one, three of the seven high circulating newspaper editors responded that their publication did not have a written correction policy. Likewise, four of the six low circulating newspaper editors said their publication did not have a written correction policy. In percentages, $43 \%$ and $66 \%$ of the high and low circulating 
newspapers, respectively, did not have written policies. As a whole, $54 \%$ of the newspapers did not have written policies.

As a whole, $54 \%$ of the newspapers did not have written policies. It should be noted that two of the newspapers listed are actually owned by one owner. The Intelligencer and Wheeling News-Register have the same owner and editor. The Intelligencer is published in the morning and the News-Register in the afternoon. Along the same lines, The Charleston Gazette and Daily Mail operate under a joint operating agreement. The Gazette is published in the mornings and the Daily Mail in the afternoons; however, the two combine to produce Saturday and Sunday issues. According to an editor at the Gazette, the newspaper does not have a formal correction policy. Reporters are responsible, if errors are brought to their attention, for typing up their own corrections and making them available for publication. On the opposite end of the spectrum, the Daily Mail features a correction policy in the paper on a daily basis. According to Monica Orosz, life section editor for the Daily Mail, in general, corrections are run when a reporter and source agree that an error occurred.

All three questions go hand in hand. In all cases, except one, those editors who answered "yes" or "no" to the first question answered the same for the next two. In those cases where all three questions were answered in the affirmative, the researcher made copies of the policies published in the newspapers. A total of five policies were collected and analyzed for their similarities and differences. The policies printed in The Intelligencer and News-Register were identical except for the name of the newspaper mentioned in the policy. Those two policies, as well as those printed in the Weirton Daily Times and Elkins Inter-Mountain, used verbs such as "strives," "seeks" and "cares” in 
their policies. The policy printed in The Herald-Dispatch simply stated the publication “will correct any reporting or editing errors that appear in its news columns."

In four of the five policies, the name and telephone number of the editor who was responsible for corrections was listed within the body of the policy. In the fifth policy, from The Herald-Dispatch, readers were simply directed to the city desk. The policies in the Wheeling newspapers also stated that if the editor is unavailable, "ask to speak to another editor who can deal with your concern.” They were the only policies to list an additional source if the first was unavailable.

All editors were asked questions four, five and six with editors of newspapers with written policies also being asked questions seven and eight.

The researcher has already determined that objective errors occur most often in West Virginia daily newspapers; however, when asking question four, she wanted to compare reality with the editor's perceptions. All interviewees were explained the difference between objective and subjective errors to ensure a proper answer. Since questions four and six are the only closed-ended questions, they are the only ones represented in the table below.

4. What type of error, objective or subjective, occurs most often in your publication?

5. How do you and/or your staff decide what type of errors need a printed correction?

6. Are writers penalized for having errors in their stories?

7. How long has the policy existed?

8. What prompted its creation? 
Table 10. Newspaper Editors Responses to Questions Four and Six

\begin{tabular}{|c|c|c|c|}
\hline Newspaper Name & Question 4 & Type of objective error* & Question 6 \\
Charleston Gazette & Objective & - & No \\
Charleston Daily Mail & Objective & Name/title \& dates/times & No \\
Huntington Herald-Dispatch & Objective & - & No \\
Beckley Register-Herald & Objective & - & No \\
Parkersburg News and Sentinel & Objective & Name/title & No \\
Wheeling Intelligencer & Objective & - & No \\
Martinsburg Journal & Objective & Name/title & No \\
Wheeling News Register & Objective & - & No \\
Elkins Inter-Mountain & Objective & Name/title & No \\
Logan Banner & Objective & Name/title & No \\
Weirton Daily Times & Objective & Name/title & No \\
Moundsville Daily Echo & Objective & Name/title & No \\
Wayne County News & Objective & Number & No \\
\hline
\end{tabular}

*Not all editors designated a specific type of objective error that they thought occurred most often in their publications.

As shown in the table above, hypothesis three, "When surveyed, newspaper editors will say objective errors occur most often in their publications” can be accepted. One hundred percent of the 13 editors surveyed said objective type errors are corrected most often in their publications. Although not all editors provided a specific type of objective error that is corrected most often, $88 \%$ of those who did agreed that they see the “name/title” errors the most. Along with the name and title errors, several editors talked about their need to run clarifications, which are treated differently than corrections, when printing information from police reports. "We get arrest notifications from the magistrates’ office. Most often we will have someone call down and say 'That's not me. There's someone else with that same name.' In that case, we check their driver's license information and confirm it isn't them with the magistrate. Then the clarification runs,” said Myriam Walton, editor of the Moundsville Daily Echo. Mike Browning, managing editor of the Logan Banner, had also come across similar situations. 
With regard to question six, all of the editors said their reporters are not penalized for having errors in their stories. However, several editors noted the presence of a disciplinary process that was only used in severe cases. Matthew Bieniek, city editor of the Martinsburg Journal, said, "We have an internal disciplinary process, but the error would have to be very severe for it to into effect.”

None of the five editors who answered questions seven and eight knew an exact time frame for how long the written policies had existed. However, only two of the five knew of a reason why the policies were created. According to Monica Orosz, life section editor of the Charleston Daily Mail, the publication's printed correction policy is "all part of the trend that we need to be accessible to our readers.” Likewise, John McCabe, editor of the Wheeling News-Register and The Intelligencer, said that the printed policy "gives us more credibility with our readers.” Although he was not directly asked questions seven and eight, Charlie Shelton, news editor of the Wayne County News, did comment on his publications lack of a written, published policy: "We are a small newspaper. Other newspapers bury corrections inside, but our owner has a policy of running them on the front page. If we make a mistake, we will make it right for you. We're a pretty small town and that is probably why we don't have a policy.” When asked how they handled errors when they occurred, the editors of publications without policies agreed that if there is a problem, especially in the smaller towns, people would get in touch with them.

To assess the last hypothesis - A majority of publications will have a standard place within the newspaper where readers can find corrections - the researcher observed the placement of all corrections in all 18 West Virginia daily newspapers over the 60-day time period. The table below indicates the newspaper name and if all of the corrections found appeared in the same location. The corrections were categorized by their location 
(above or below the fold in the newspaper) as well as their position on the page (bottom or top left, right or center). Since the researcher was attempting to find a pattern in the location and position of the corrections, newspapers where zero or one corrections were found were eliminated from the table below.

Table 11. Locations and Positions of Corrections In Newspapers

\begin{tabular}{|clc|}
\hline Newspaper Name & Location & Position on page \\
\hline Charleston Gazette & Below the fold & Varies \\
Huntington Herald-Dispatch & Below the fold & Left \\
Beckley Register-Herald & Varies & Varies \\
Parkersburg News and Sentinel & Below the fold & Varies \\
Wheeling Intelligencer & Below the fold & Center \\
Martinsburg Journal & Below the fold & Varies \\
Wheeling News Register & Below the fold & Center \\
Elkins Inter-Mountain & Below the fold & Left \\
Weirton Daily Times & Below the fold & Left \\
Bluefield Daily Telegraph & Below the fold & Right \\
Clarksburg Exponent Telegram & Below the fold & Varies \\
Dominion Post & Below the fold & Varies \\
Williamson Daily News & Below the fold & Left \\
Fairmont Times & Below the fold & Varies \\
\hline
\end{tabular}

As can be seen in the table above, 13 of the 14 publications printed corrections below the fold in the newspaper. The only exception to this was with the Beckley Register-Herald. Although the corrections were always within the first three pages of the newspaper, they appeared above and below the fold as well as in different positions on the page. As far as the position of the corrections on the pages of the newspapers, seven of the 14 papers varied the positions of the corrections. Several papers, including the Wheeling News-Register, The Intelligencer, The Dominion Post, The Herald-Dispatch and the Weirton Daily Times, all listed corrections in the same position, on the same page, in conjunction with their corrections policies. 


\section{CHAPTER 5}

\section{CONCLUSION}

The purpose of this research was not to determine the credibility of West Virginia's daily newspapers, but rather to see what type of errors were corrected most often - not only from the perspective of the researcher, but from the editors as well. Throughout the course of this study, as well as the pilot study, the researcher concluded that errors in names and titles that appear within news stories are the most common type of error corrected.

As was stated in the literature review, the Associated Press Managing Editors performed an informal survey of readers to determine why inaccuracies go unreported. ${ }^{118}$ Doubts about the interest of the newspaper and not knowing whom to contact were the reasons readers did not report inaccuracies. ${ }^{119}$ The results of this study show that a majority of West Virginia daily newspapers with written, published correction policies make the contact information of an editor responsible for corrections available to their readers. The data found through this research does not support the idea that newspapers with printed correction policies run more corrections. With the exception of the Dominion Post, where the policy runs on a daily basis and 28 corrections were found in the 60-day time period, a low number (ranging from 7 -10) of corrections was found in the other five newspapers.

Likewise, in a 1999 ASNE study, participants noted that when papers are published with errors in them usually corrections follow; however, only 19 percent of readers said they “always” saw corrections as opposed to the 40 percent who only

\footnotetext{
${ }^{118}$ Nat Hentoff, “A Few Good Ombuds.,” Editor and Publisher 136 (27): 30

${ }^{119}$ Ibid., 30
} 
“sometimes” saw them. ${ }^{120}$ However, the majority of West Virginia’s high-circulating daily newspapers provide their readers with a designated place where corrections can be found.

As was found in the literature review, newspapers tend to correct "objective" type errors most often, with errors in names and titles occurring most often. These results were first found by Charnley in 1967 and have been duplicated over the years on a national level. The results of this study show that the same holds true in the state of West Virginia.

Overall, in the time period of this study, West Virginia’s daily newspapers corrected very few subjective type errors and corrected name and title errors more often than any other type of objective error. A majority of the newspapers provide their readers with ample ways to reach them if there is a problem, as well as space within the newspapers where readers can find corrections.

Limitations of this research include the time period in which the corrections were gathered and the number of editors who were surveyed. Only a 60-day times period was used to gather corrections. This time period only allotted 151 corrections. It's plausible that an increase in the time period would increase the amount of corrections. An increase in the amount of corrections to 200 and above would allow for an accurate gauge in statistical validity. Also, not all of the editors of West Virginia's daily newspapers were surveyed. There were several of the larger circulating newspapers whose editors were unavailable.

This research produces a wealth of future research opportunities. Expansion could include using this same methodology to determine how West Virginia's weekly and semi-weekly newspapers handle errors and corrections. This would allow for a

\footnotetext{
${ }^{120}$ American Society of Newspaper Editors, "Building Reader Credibility,: available from http://www.asne.org/index.cfm?id=3726; Internet, accessed 23 January 2004
} 
comparison between them and daily newspapers. Research could also be conducted to see if those West Virginia daily newspapers that have published corrections policies publish more corrections. As Whitney noted in his study, readers are more concerned with the "subjective” type errors, but newspapers are more concerned with "objective” ones and tend to correct them more often. ${ }^{121}$ Since this research raises a list of questions regarding subjective errors, future research could focus solely on them - Why are subjective errors corrected less often than objective errors? What are the perceptions of editors and readers about subjective errors? Where is the gap between newspapers and their readers? Are the subjective type errors being reported but newspapers are choosing to ignore them? Are readers just not reporting them? If so, why? How can the two work together to bridge the gap? To answers these questions, focus groups with both editors and readers could prove to be helpful. Future research could also focus on the time periods in which the stories where errors were found were produced. Were the majority of the stories written in a short amount of time - especially those found in The Charleston Gazette and Dominion Post? 


\section{BIBLIOGRAPHY}

Abel, John D. and Michael O. Wirth, “Newspaper vs. TV Credibility for Local News,” Journalism Quarterly 54 (1977): 371-375

American Society of Newspaper Editors, "Building Reader Credibility,: available from http://www.asne.org/index.cfm?id=3726; Internet, accessed 23 January 2004

Barkin, Steve M. and Mark R. Levy, “All the News That's Fit To Correct: Corrections in the Times and the Post,” Journalism Quarterly, 60 (Summer 1983): 220-233

Berry, Fred C., “A Study of Accuracy in Local News Stories of Three Dailies,” Journalism Quarterly 44 (1967): 482-490

Braman, Sandra, "Public Expectations of Media Versus Standards in Codes of Ethics,” Journalism Quarterly 62 (winter 1985): 71-77, 240

Brown, Charles H, “Majority of Readers Give Papers and A for Accuracy,” Editor and Publisher (1965): 12-13, 63

Charnley, Mitchell V, "Preliminary Notes on A Study of Newspaper Accuracy,” Journalism Quarterly 13 (winter 1936): 394-401

Fowler, Gilbert L. and Tommy L. Mumert, “A Survey of Correction Policies of Arkansas Newspapers,” Journalism Quarterly, 65:854 (Winter 1988)

Getlin, Josh, “Ombudsman: Monitoring Yourself,” Columbia Journalism Review 38 (March/April 2000): 51

Graziano, Cecilie and Kristin McGrath, “Measuring the Concept of Credibility,” Journalism Quarterly 63 (autumn 1986): 451-462

Gunther, Albert C., "Biased Press Or Biased Public? Attitudes Toward Media Coverage of Social Groups,” Public Opinion Quarterly 56 (1992): 155-163

Hart, Ariel, “Delusions Of Accuracy,” Columbia Journalism Review 42 (Jul/Aug 2003): 2021

Hentoff, Nat, “A Few Good Ombuds.,” Editor and Publisher 136 (27): 30-32

Jacobson, Harvey K., "Mass Media Believability: A Study of Receiver Judgments,” Journalism Quarterly 46 (spring 1969): 20-28

Lee, Raymond S.H., “Credibility of Newspaper and TV News,” Journalism Quarterly 55 (summer 1978): 282-290

Lewin, Kurt, "Frontiers in Group Dynamics: Channels of Group Life; Social Planning and Action Research,” Human Relations 1 (November 1947): 143-153 
Lawrence, Gary C. and David L. Grey, "Subjective Inaccuracies in Local News Reporting," Journalism Quarterly 46 (winter 1969): 753-757

Maier, Scott, “Getting It Right? Not in 59 Percent of Stories,” Newspaper Research Journal 23 (winter 2002): 10-24

Meyers, Christopher, “Creating an Effective Newspaper Ombudsman Position,” Journal of Mass Media Ethics 15 (4): 248-256

Meyer, Philip, “Defining and Measuring Credibility Of Newspapers: Developing and Index,” Journalism Quarterly 65 (fall 1988): 567-574

Overholser, Geneva, “Careening Toward Extinction With Salvation Firmly in Hand," Columbia Journalism Review 41 (Sept/Oct 2002): 75

Pagano, Penny, "Public Perspectives On The Press,” American Journalism Review 15 (December 1993): 40-46

Paterno, Susan, “I Can Explain,” American Journalism Review 20 (July/Aug 1998): 25-29

Pritchard, David, “The Impact of Newspaper Ombudsmen on Journalists' Attitudes,” Journalism Quarterly 70 (spring 1993): 77-85

Rimmer, Tony and David Weaver, "Different Questions, Different Answers? Media Use and Media Credibility,” Journalism Quarterly 64 (1987): 28-44

Rieder, Rem, “Wanted: One Good Ombudsman,” American Journalism Review 25 (Aug/Sept 2003): 6, 65

Russial, John, “Goodbye copy desks, hello trouble?” Newspaper Research Journal 19 (spring 1998): 2

Shepard, Alicia C., “Going Public,” American Journalism Review 19 (April 1997): 25-29

Shepard, Alicia C., “Legislating Ethics,” American Journalism Review 16 (Jan/Feb 1994): 37-41

Shoemaker, Pamela J. et al., "Individual and Routine Forces in Gatekeeping,” Journalism and Mass Communication Quarterly 78 (summer 2001): 233-242

Shoemaker, Pamela J. and Stephen D. Reese, Mediating the Message: Theories of Influences on Mass Media Content (NY: Longman, 1996): 261-272

Singletary, Michael W. and Gerald Stone, Communication Theory and Research Application (Iowa State Univeristy Press, 1988), 22-28 
Society of Professional Journalists, Codes of Ethics, available from http://www.spj.org/ethics_code.asp; Internet, accessed 28 January 2004

Strentz, Herb, “Universal Ethical Standards,” Journal of Mass Media Ethics 17 (4): 263-276

Ugland, Erik Forde and Jack Breslin, "Minnesota News Council: Principles, Precedent, and Moral Authority,” Journal of Mass Media Ethics 15 (4): 232-247

White, David Manning, “The 'Gate Keeper:' A Case Study In the Selection of News,” Journalism Quarterly 27 (fall 1950): 383-390

Whitney, D. Charles, "Begging your pardon. Corrections and corrections policies at twelve US newspapers,” New York Gannett Center for Media Studies, (1986): 8-15 


\section{RESUME}

\section{LINDSAY E. ALTOBELLO}

2003 - 2005 West Virginia University

Master of Science in Journalism

Will complete degree program in May

2000 - 2002 West Virginia University

Bachelor of Science in Journalism

1998 - $2000 \quad$ Potomac State College

Associate of Arts in Journalism
Morgantown, WV

Morgantown, WV

Keyser, WV

\section{CAREER-RELATED WORK EXPERIENCE}

2004 - 2005 Robert C. Byrd Health Sciences Center Morgantown, WV

Graduate Assistant - Planning, Marketing and Communications

Wrote and edited news releases, newsletter articles and feature stories

Maintained an online collection of health-related news stories

Assisted with planning and execution of special events

Served as on-campus escort for media representatives

1999 - $2000 \quad$ Potomac State College

Keyser, WV

Campus News Editor - The Pasquino

Wrote and edited hard news stories and feature articles

Designed page layouts using Adobe PageMaker

WORK EXPERIENCE

Aug. 2002 - Jan. 2003 Walt Disney World College Program Orlando, FL

Merchandise Hostess - Main Street, Magic Kingdom

1998 - Present Domino's Pizza

Delivery Driver, Customer Service Representative, Assistant Manager

PROFESSIONAL SKILLS

$\begin{array}{ll}\text { Microsoft Word } & \text { HTML Coding } \\ \text { Microsoft Excel } & \text { Photography } \\ \text { Microsoft PowerPoint } & \text { Proofreading } \\ & \text { Copy Editing }\end{array}$

